\title{
TEKNOLOGI PENGOLAHAN TONGKOL JAGUNG (ZEA MAYS) MENJADI BIOETANOL SEBAGAI BIOENERGI ALTERNATIF
}

\author{
Whydiantoro $^{1)}$, Dony Susnadi ${ }^{2)}$ \\ ${ }^{1}$ Fakultas Teknik, Universitas Majalengka \\ email: why@ft.unma.ac.id, dys@ft.unma.ac.id
}

\begin{abstract}
Waste from harvested corn, especially cob, is a lignocellulose source that has not been utilized effectively and can be used as a material for bioethanol production. Bioethanol is one of the biofuels that is present as an alternative fuel that is environmentally friendly and renewable. The purpose of this research is to determine the ethanol content produced in the bioconversion of cellulose corn cobs waste. In this study, the methods used are delignification, hydrolysis, fermentation, and distillation. Research activities begin with refining the waste of corn harvest into flour. Then it was delignified using $\mathrm{NaOH} \%$ with a variation of immersion time of 6 hours, 12 hours and 24 hours. The purpose of this delignification is to reduce the lignin content found in corn cobs biomass. Before the delignification of lignin contained was $13.80 \%$ after delignification of lignin content decreased at 6 hours soaking time to $11.11 \%, 12$ hours immersion time $9.26 \%$ and $8.94 \% 24$ hours soaking time, then hydrolyzed using H2SO4 concentration $15 \%$, then fermented by filtrate using Saccharomyces Cerevisiae microbes found in bread yeast, fermentation is carried out for three days under anaerobic conditions. The fermentation results were purified by distillation at a temperature of $78^{\circ} \mathrm{C}-80^{\circ} \mathrm{C}$ and the highest ethanol content was obtained at $0.5 \%$ with an amount of $11 \mathrm{ml}$ distillate.
\end{abstract}

Keywords: Bioetanol, Tongkol Jagung, Bioetanol

\section{PENDAhuluan}

Salah satu limbah pertanian ber-lignoselulosa yang dapat digunakan sebagai bahan baku pembuatan bioetanol adalah limbah jagung. Limbah jagung meliputi jerami dan tongkol. Penggunaan jerami jagung semakin populer untuk makanan ternak, sedangkan untuk tongkol belum ada pemanfaatan yang bernilai ekonomi [1]. Pemanfaatan tongkol jagung sebagai alternatif energi terbarukan berupa bioetanol dapat diolah melalui proses Pretreatment, hidrolisis, fermentasi dan destilasi [2]. Bioetanol $(\mathrm{C} 2 \mathrm{H} 5 \mathrm{OH})$ merupakan salah satu biofuel yang hadir sebagai bahan bakar alternatif yang ramah lingkungan dan sifatnya yang terbarukan. Bahan bakar cair yang berasal dari sumber daya-sumber daya lignoselulosa terbarukan memberikan penawaran yang unik dan masa depan yang diinginkan karena terdapat jaminan distribusi sumber daya, angka konflik antara pangan dan pakan rendah, dan hemat bahan energi.

Teknologi pengolahan tongkol jagung menjadi bioetanol umumnya melalui tahapan proses delignifikasi, hidrolisis, fermentasi, dan destilasi. Proses delignifikasi dilakukan untuk mengurangi kadar lignin agar selulosa mudah dihidrolis. Proses delignifikas dapat dilakukan dengan menggunakan zat kimia basa seperti

Computer Science | Industrial Engineering | Mechanic Engineering | Civil Engineering 
natrium hidroksida. Dalam hal ini, selulosa dapat dimanfaatkan untuk menghasilkan etanol dengan fermentasi menggunakan Saccharomyces cerevisiae. Sebelum difermentasi, selulosa tersebut harus dihidrolis terlebih dahulu menjadi gula-gula sederhana. Proses hidrolisis yang umum digunakan pada industri etanol adalah menggunakan hidrolisis asam dengan menggunakan asam sulfat (H2SO4) atau dengan menggunakan asam klorida ( $\mathrm{HCl})$ [3]. Setelah fermentasi, kemudian dilakukan pemurnian terhdap etanol yaitu dengan cara destilasi.

\section{TINJAUAN PUSTAKA}

\section{Tanaman Jagung}

Secara struktural, biji jagung yang telah matang terdiri atas empat bagian utama, yaitu perikarp, lembaga, endosperm, dan tip kap (Gambar 2.2). Perikarp merupakan lapisan pembungkus biji yang berubah cepat selama proses pembentukan biji. Pada waktu kariopsis masih muda, sel-selnya kecil dan tipis, tetapi sel-sel itu berkembang seiring dengan bertambahnya umur biji. Pada taraf tertentu lapisan ini membentuk membran yang dikenal sebagai kulit biji atau testa/aleuron yang secara morfologi adalah bagian endosperm. Bobot lapisan aleuron sekitar 3\% dari keseluruhan biji[4]. Lembaga merupakan bagian yang cukup besar. Pada biji jagung tipe gigi kuda, lembaga meliputi $11,5 \%$ dari bobot keseluruhan biji. Lembaga ini sendiri sebenarnya tersusun atas dua bagian yaitu skutelum dan poros embrio (embryonic axis). Endosperm merupakan bagian terbesar dari biji jagung, yaitu sekitar $85 \%$, hampir seluruhnya terdiri atas karbohidrat dari bagian yang lunak (floury endosperm) dan bagian yang keras (horny endosperm) (Wilson dalam Balai Penelitian Struktur, Komposisi, dan Nutrisi Jagung, Suarni dan Widowati, 2016:411). Lembaga terdiri atas plumula, radikel, dan skutelum, yaitu sekitar $10 \%$ dan perikarp 5\%. Perikarp merupakan lapisan luar biji yang dilapisi oleh testa dan lapisan aleuron. Lapisan aleuron mengandung $10 \%$ protein [5].

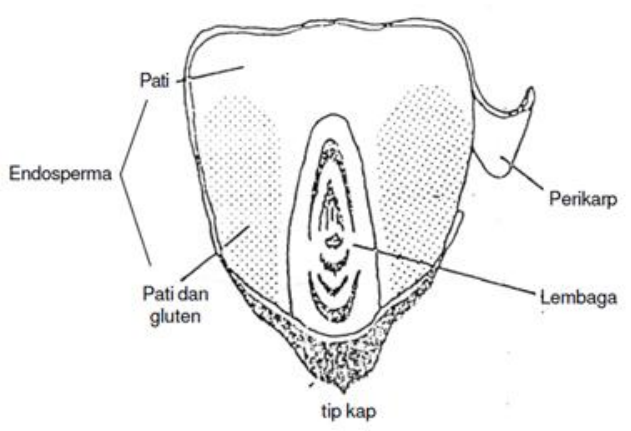

Gambar 1 Struktur Jagung [4]

\section{Lignin}

Lignin merupakan jaringan polimer fenolik yang berfungsi merekatkan serat selulosa sehingga menjadi sangat kuat. Kekuatan ikatan lignin merupakan salah satu penghalang pada proses hidrolisis yang pada akhirnya diterapkan metode delignifikasi untuk menghilangkan lignin tanpa mengurangi serat selusosa secara signifikan. Pada proses konversi biomassa menjadi etanol dengan proses hidrolisis dan fermentasi kekuatan ikatan lignin juga menjadi penghalang dalam proses hidrolisisnya. Secara umum struktur lignin yang cukup kompleks dapat dilihat pada Gambar 2.

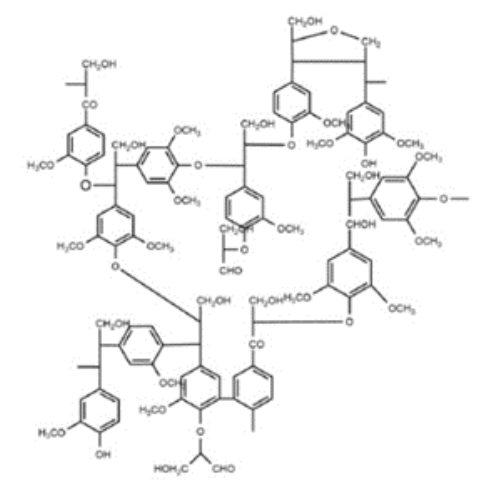

Gambar 2 Struktur Lignin [5]

Lignin adalah polimer tiga dimensi yang terdiri dari unit fenil propana yang diikat dengan ikatan eter (COC) dan ikatan karbon (CC). Lignin bersifat hidrofobik dan melindungi 
selulosa sehigga strukturnya bersifat kaku (rigid). Adanya ikatan aril alkil dan ikatan eter di dalamnya menyebabkan lignin menjadi tahan terhadap proses hidrolisis dari asam-asam universal. Lignin dapat dioksidasi oleh larutan alkali dan oksidator lainnya. Pada suhu tinggi, lignin dapat mengalami perubahan menjadi asam format, metanol, asam asetat, aseton dan vanili[5]

\section{Bioetanol}

Bioetanol bersumber dari karbohidrat yang potensial sebagai bahan baku seperti tebu, nira sorgum, ubi kayu, garut, ubi jalar, sagu, jagung: jerami, bonggol jagung dan kayu. Setelah melalui proses fermentasi, dihasilkan etanol. Etanol adalah senyawa organik yang terdiri dari karbon, hidrogen dan oksigen, sehingga dapat dilihat sebagai derivat senyawa hidrokarbon yang mempunyai gugus hidroksil dengan rumus $\mathrm{C} 2 \mathrm{H} 5 \mathrm{OH}$.

Etanol merupakan zat cair, tidak berwarna, berbau spesifik, mudah terbakar dan menguap, dapat bercampur dalam air dengan segala perbandingan. Penggunaan bioetanol di antaranya adalah sebagai bahan baku industri, minuman, farmasi, kosmetika, dan bahan bakar [6].

Produksi Bioetanol

a. Pretreatment (Delignifikasi)

b. Produksi Gula (Sakarifikasi/ Hidrolisis)

c. Produksi Etanol (Proses Fermentasi)

d. Pemurnian Etanol (Proses Destilasi)

\section{METODE PENELITIAN}

1. Tahap persiapan

Tahap ini dimulai dengan proses pengumpulan data tentang bahan pembuatan bioetanol dan proses pembuatannya berdasarkan referensi yang tersedia. Setelah data terkumpul dilanjutkan dengan proses penentuan pembuat bioetanol dari tongkol jagung.

2. Tahap pelaksanaan

Tahap pelaksanaan pembuatan bioetanol dari tongkol jagung ini terdiri dari beberapa tahap yaitu:
1) Preparasi bahan;
2) Pretreatment (delignifikasi);
3) Produksi gula (sarifikasi/hidrolisis);
4) Analisa kadar glukosa ;
5) Proses fermentasi.
3. Pemurnain (destilasi)

Cairan fermentasi dipanaskan sampai suhu titik didih etanol,kurang lebih $78^{\circ}$. Etanol akan menguap dan uap etanol ditampung/disalurkan melalui pipa/tabung kondensor. Di tabung ini suhu uap etanol diturunkan sampai di bawah titik didihnya, etanol akan berubah dari fase gas ke fase cair. Selanjutnya etanol yang sudah mencair ditampung kedalam gelas beker.

3. Analisa kadar etanol

Etanol dari hasil destilasi diukur dengan menggunakan alcohol tester. Penggunaan alkohol meter yaitu dengan memasukkan bioetanol ke dalam gelas ukur atau botol yang tingginya lebih panjang dari panjang alkohol meter. Kemudian masukkan batang alkohl meter ke dalam gelas ukur, alcohol tester akan tenggelam dan batas airnya akan menunjukkan berapa kandungan alkohol di dalam larutan tersebut.

Untuk lebih jelasnya digambarkan oleh Gambar 3 dibawah ini:

Computer Science | Industrial Engineering | Mechanic Engineering | Civil Engineering 


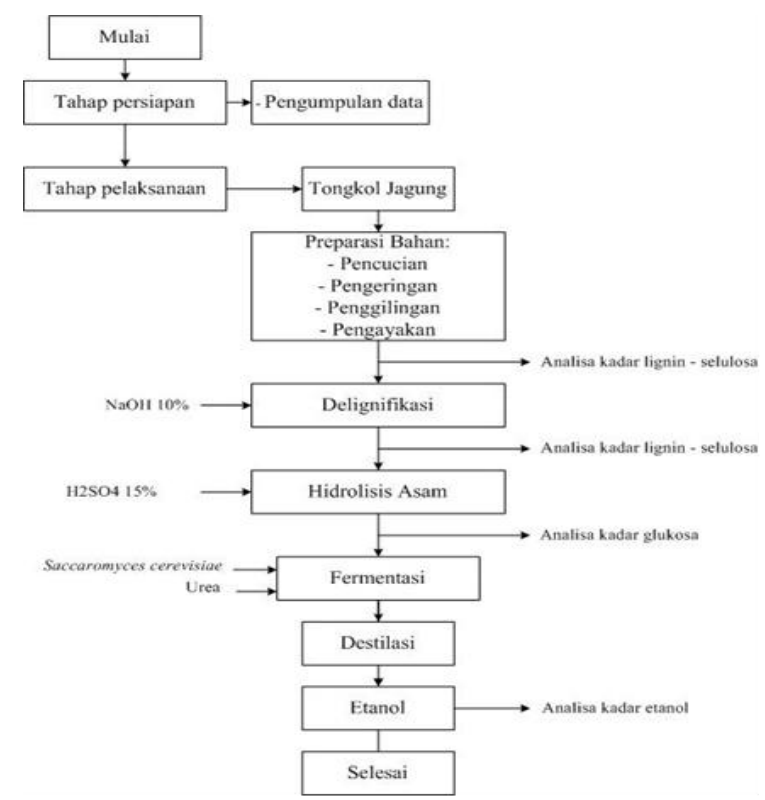

Gambar 3 Tahapan Penelitian

\section{HASIL DAN PEMBAHASAN}

1. Proses Tongkol Jagung Menjadi Serbuk.
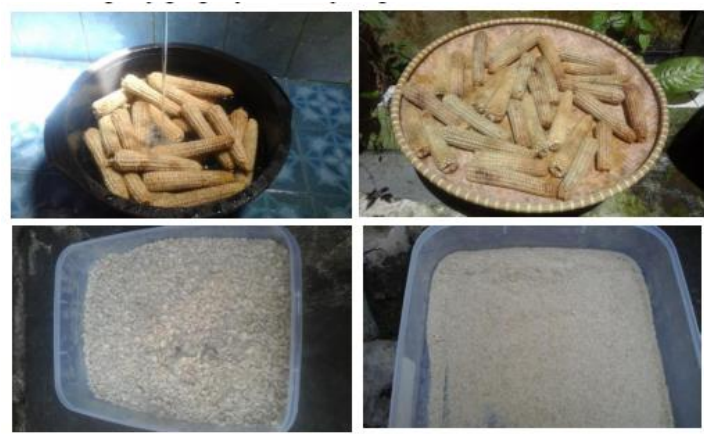

Gambar 4 Proses Preparasi Sampel

Bagian Preparasi sampel meliputi pencucian, pengeringan dan penggilingan dan pengayakan tongkol jagung hingga berupa serbuk. Tongkol jagung yang digunakan dalam penelitian ini sebanyak $2 \mathrm{~kg}$. Serbuk tongkol jagung yang dihasilkan setelah pengolahan sebanyak kurang lebih 260 gr. Hasil pengolahan tongkol jagung menjadi serbuk tongkol jagung dapat dilihat pada Gambar 4.

2. Delignifikasi

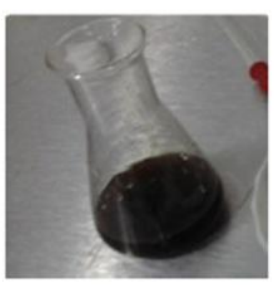

(a)

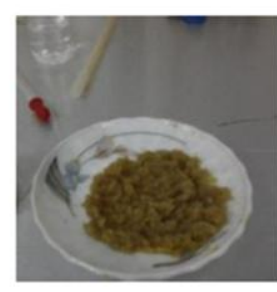

(b)
Gambar 5 Proses Delignifikasi

Proses perlakuan bahan awal dilakukan melalui proses delignifikasi. Proses tersebut dilakukan dengan tujuan untuk menyederhanakan bahan sehingga dengan mudah dapat dihidrolisis menggunakan asam, perlakuan bahan awal dilakukan dengan tujuan untuk menghilangkan bahan - bahan yang menghambat pada proses hidrolisis seperti lignin.

\section{Proses Hidrolisis}

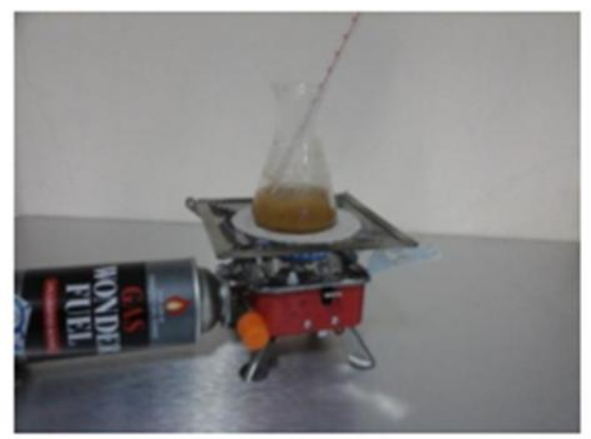

Gambar 6 Proses Hidrolisis

Pada proses hidrolisis yang pemanasannya dengan kompor terjadi di tempat terbuka dengan suhu pemanasan $100 \mathrm{oC}$ sehingga terjadi proses penguapan glukosa mengakibatkan fruktural dan HMF ikut terbuang. Akibatnya glukosa warnanya menjadi coklat muda. Hidrolisis dengan pemanasan menggunakan kompor dapat dilihat pada Gambar 6.

5. Fermentasi 


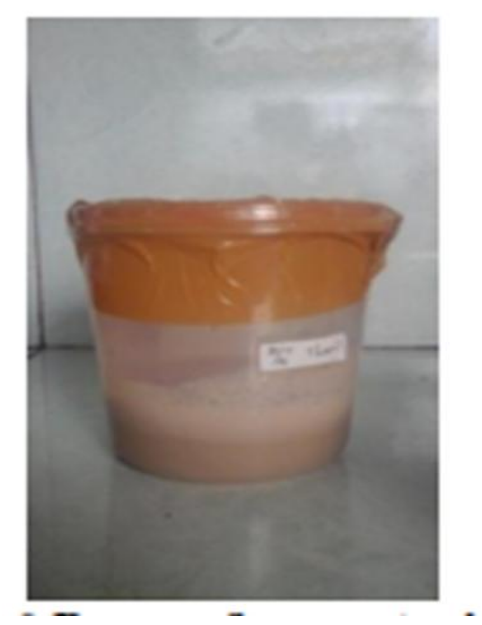

Gambar 7 Proses Fermentasi

Fermentasi merupakan suatu proses untuk mengubah bahan dasar menjadi suatu produk oleh masa sel mikroba. Produk yang diharapkan dalam proses adalah produk etanol yang diperoleh melalui konversi dari bentuk gula menjadi etanol (alkohol) dengan menggunkan mikroba Saccharomyces cerevisiae. Dalam percobaan yang dilakukan mikroba Saccharomyces cerevisiae berasal dari ragi/khamir roti (fermifan).

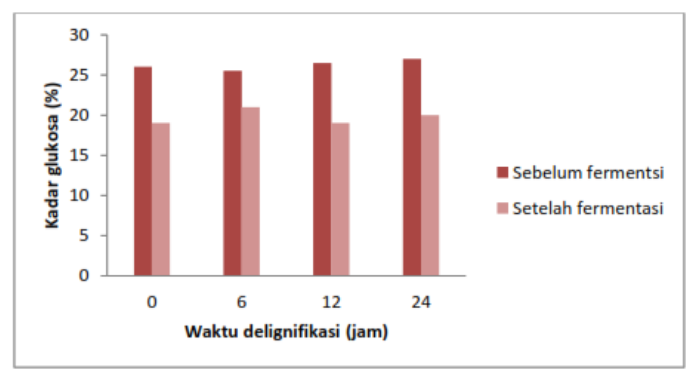

Gambar 8 Hasil Fermentasi

\begin{abstract}
Dari gambar 8 dapat dilihat adanya penurunan kadar glukosa pada waktu fermentasi. Turunnya kadar glukosa pada setiap varasi waktu delignifikasi menunjukkan adanya konversi glukosa menjadi bioetanol.
\end{abstract}

6. Destilasi

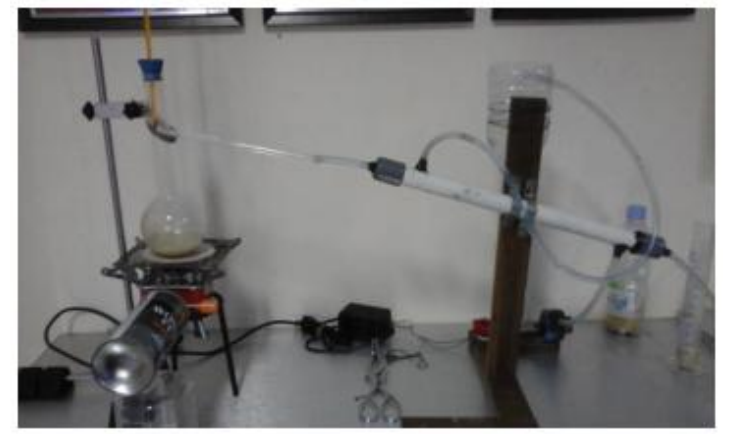

Gambar 9 Proses Destilasi

Destilasi sederhana atau destilasi biasa adalah teknik pemisahan kimia untuk memisahkan dua atau lebih komponen yang memiliki perbedaan titik didih. suatu campuran dapat dipisahkan dengan destilasi biasa ini untuk memperoleh senyawa murninya. Senyawa - senyawa yang terdapat dalam campuran akan menguap pada saat mencapai titik didih masing - masing.

\section{KESIMPULAN}

Etanol tertinggi dihasilkan dari tongkol jagung yang telah didelignifikasi 24 jam dengan kandungan ligninnya $8,94 \%$ selulosa $28,77 \%$, dan kadar glukosa $27 \%$ etanol yang didapat sebesar $0,5 \%$ dari destilat sebanyak $11 \mathrm{ml}$ yang diukur dengan menggunakan alcohol tester. Dari penelitian ini, mikroba saccaromyces cerevisiae yang digunakan dalam uji coba berpotensi sebagai agen fermentasi namun ternyata kadar etanol yang dihasilkan masih sangat rendah dan belum bisa menghasilkan energi.

\section{REFERENSI}

[1](Richana dan Suarni, dalam Jurnal Pemanfaatan Limbah Tongkol Jagung (Zea Mays) Untuk Produksi Bioetanol Menggunakan Sel Ragi Amobil Secara Berulang, Indriany, D. dkk, 2013:55)

[2](Siti Muslihah dan Yulinah, Produksi Bioetanol Dari Limbah Tongkol Jagung Sebagai Energi Alternatif Terbarukan, 2013:2)

[3](Lee et al., 1997 dalam Siti Muslihah dan 
Yulinah, Produksi Bioetanol Dari Limbah Tongkol Jagung Sebagai Energi Alternatif Terbarukan, 2013:1

[4] (Inglett dalam Balai Penelitian Struktur, Komposisi, dan Nutrisi Jagung, Suarni dan Widowati, 2016:411)

[5] Mertz dalam Balai Penelitian Struktur, Komposisi, dan Nutrisi Jagung, Suarni dan Widowati, 2016:411

[6]Sunarno dalam Skipsi Pengaruh Konsentrasi Naoh Pada Karakterisasi A-Selulosa Dari Tandan Kosong Sawit (Tks) Tazkiya, 2016:12

[7] Judoamidjojo dalam Skipsi Pengaruh Konsentrasi Naoh Pada Karakterisasi ASelulosa Dari Tandan Kosong Sawit (Tks), Tazkiya, 2016:12

[8] Ahmad R.F., dkk, Pembuatan Bietanol Dari Limbah Tongkol Jagung Dengan Variasi Konsentrasi Asam Klorida Dan Waktu Fermentasi, 2013:63 